\title{
Research on Learning-Centered Business English Teaching Model Based on Internet Plus
}

\author{
Xiaomei Wang ${ }^{1, *}$

\begin{abstract}
${ }^{1}$ College of Applied Science and Technology, Beijing Union University, Beijing, 100101, China
\end{abstract} \\ *Corresponding author. Email:ldtwangxiaomei@buu.edu.cn
}

\begin{abstract}
In order to improve the teaching effect, this paper introduces the new learning-centered blended teaching model based on Internet Plus to business English teaching practice. Before face-to-face classroom teaching, teachers create learning resources according to the teaching objectives and students' basic situations, create real learning environments and tasks according to the teaching contents, and students learn online under the teachers' guidance. In classroom teaching, teachers focus on the difficult points and students' problems; activities are designed to encourage students' participation. After class, online quizzes and tests are provided for both teachers and students to get right and timely feedback; personalized supplemental learning materials are then recommended for students to consolidate and improve their knowledge online. The experimental teaching practice shows that more than $80 \%$ of students accept the new teaching model, and the average grade performance of students who participated in the new teaching model increased by $20.8 \%$ compared with those in the traditional teaching model. The new learning-centered teaching model improves students' learning autonomy and enhances the effectiveness of business English teaching.
\end{abstract}

Keywords: internet plus, learning-centered, business English, teaching model, formative evaluation

\section{INTRODUCTION}

With the deepening integration of the world economy, more and more Chinese companies are moving towards international stage and often encounter foreign activities in business, such as communication and business negotiation with foreign companies. Therefore, business industries have put forward higher requirements on business English talents training. Business English talents are required to deal with foreign activities proficiently, to communicate with English as a tool in foreign-related workplace environment, to perform tasks and solve problems with knowledge both in English and business[1].

Internet Plus environment has provided a material basis for business English talent training. For example, when students lack a good English language environment for communication training, Internet platform can create a relatively suitable language atmosphere. The development of information technology, especially the application of Internet in education, has enabled learners to get access to learning resources according to their own learning needs, interests and characteristics, to personalized guidance and services, to control learning process independently thus to make learning more efficient. With the advent of the information era, the traditional teaching-centered teaching model is gradually being transformed into a modern learning-centered teaching model[2]. It is urgent to explore how to combine network technology and resources with business English talent training, how to promote the integration of business English teaching and Internet Plus, to change the traditional English classroom teaching model, to stress learners' individuality, to stimulate students' interest in learning, thus to improve learners' business English application ability.

\section{THEORETICAL FOUNDATIONS OF LEARNING-CENTERED TEACHING}

Researches on learning-centered teaching model have been made from different perspectives by many scholars both in China and abroad. Jean Piaget and Lev Vygotsky have studied learning-centered teaching from the perspective of constructivism[3]; Maryellen Weimer has studied the components and implementation methods of learningcentered teaching in practice. Among Chinese scholars, Zhu Yonghe has studied the theoretical basis of learningcentered teaching model from a multi-dimensional perspective, and Yang Yunqiang has explored the evaluation of learning-centered teaching in undergraduate classroom.

The most influential of these studies is that based on constructivism. Constructivism holds that what students learn does not rely only on direct instruction from the teacher, but also on their own construction of knowledge. It is the student who is the center of learning. As the subject of learning and teaching, students need to have their own perspectives and awareness, and to express their own views. According to Piaget, learners should consciously, autonomously and actively filter, process and construct what they learn. It is the duty of teachers to provide opportunities and spaces for students to experiment and 
experience and to finish the learning process. Constructivism focuses on learning environment creation. It holds that teachers should create right scenario for students, provide students with more space to construct ideas, and enable students to construct knowledge in a specific learning environment. Teachers act as supporter and guider in the learning process. Constructivism highlights cooperative learning, in which each individual has a different understanding of knowledge and employs different learning methods. Cooperative learning activities create more opportunities for interaction and communication between students, so that students have access to a wider range of learning styles and thus their learning abilities are enhanced. Constructivism puts emphasis on the design and development of teaching resources, which help students develop appropriate learning styles and construct knowledge of the subject. Vygotsky believes that the leap from learners' current level of knowledge and ability to a higher level needs to be enlightened by the educator who builds a ladder or scaffold for them. In the process, teachers accompany and guide them. Teaching evaluation system should be complete and effective, including students' self-evaluation, peer-studentgroup evaluation, teacher evaluation and peer-teacherstudent evaluation.

\section{LEARNING-CENTERED BUSINESS ENGLISH TEACHING MODEL}

The learning-centered teaching model based on Internet Plus is aimed at individualized cultivation of students, respecting students' individual differences and emphasizing the personalized support of information technology. The Learning-Centered business English teaching model is shown in Fig.1.

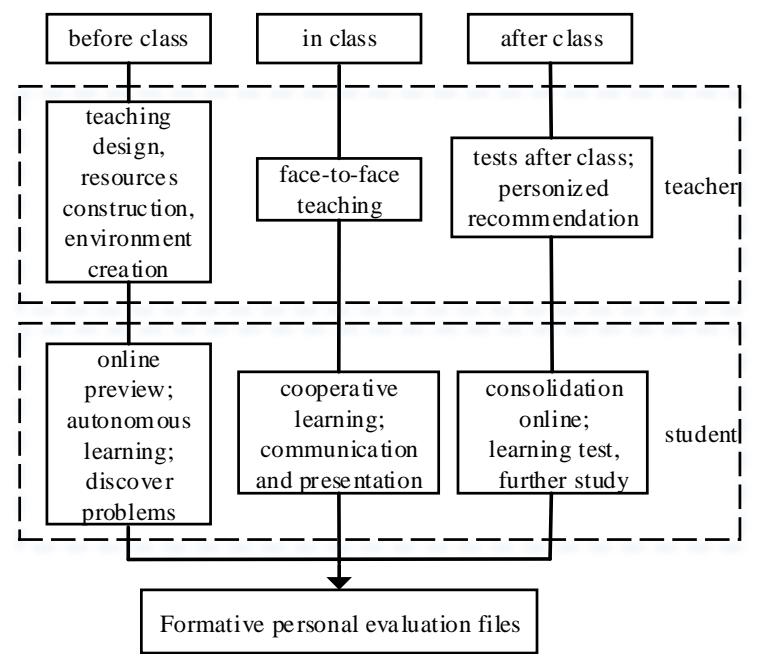

Figure 1. Learning-centered business English teaching model based on Internet Plus

Before face-to-face business English classroom teaching, teachers design the teaching, plan the lesson, create learning resources according to the teaching objectives and the target students, and create scenarios according to the teaching contents. Students preview and self-study online under the instruction of the teacher, such as watching the micro-lesson videos before class to learn more about the course, conducting independent inquiry learning, and discovering difficult points etc..

In the classroom teaching, teachers give face-to-face lectures to explain teaching difficulties and students confusions and problems in their preview; students work together and make presentation. In this way, interaction between teacher and students and among students can be fully utilized during classroom teaching, thus completing teaching tasks effectively within the limited time.

After class, teachers initiate post-class quizzes or tests on the learning platform. According to the testing results, teachers recommend additional learning materials and resources and assign different tasks and exercises to different individual students. Students use their spare time to learn online, to fill in gaps, and to expand their learning according to their own interests.

The learning-centered teaching model based on Internet Plus has brought a profound change and reform to business English teaching.

Firstly, creation and construction of an intelligent business English teaching environment. According to the laws of language learning, creating suitable language environment is crucial. As applied linguist S.P. Corder says, language teaching is not just to teach students a language, but to create an environment that is conducive to learning a foreign language. In other words, language learners can only naturally acquire relevant language knowledge in a specific context. In the context of Internet Plus, business English education is integrated with Internet technology, and Internet technology provides more possibilities and opportunities for English teaching, as well as more resources and cases for creating scenarios for English education. In practical classroom teaching, teachers make full use of various favorable resources on the Internet to create a realistic business English language environment, create targeted learning scenarios for students, deepen students' impression on knowledge, promote students' learning and application of business English knowledge in practice, thus to improve students' comprehensive application skills and abilities.

Secondly, application of blended business English teaching model. Along with the development of Internet technology, a variety of hybrid teaching modes have emerged, such as micro-lessons, massive open online courses (MOOCs) and flipped classrooms, which are the latest developments in the educational revolution, and are important manifestations of the shift from a single offline format to a blended online and offline approach to classroom teaching[5]. The new teaching models highlight studentcentered teaching principle. The flipped classroom is a reversal of the roles of teachers and students, i.e., from the traditional "teacher talking and students listening" to "students talking and teachers listening"; it is also a reversal of the roles before and after class, i.e., from the traditional "learning and practicing" to "teaching and practicing". The flipped classroom is "learning before class 
and practicing in class". For business English courses, the implementation of flipped classroom is of great significance to improve students' language competence in listening, speaking, reading and writing, as well as to stimulate their interest in learning[6]. In practical business English teaching, the flipped classroom can not only satisfy business English majors' self-paced independent English learning to fill in the gaps and consolidate the knowledge they have learned before, but also make use of the excellent business English teaching resources on the Internet and promote the internationalization of business English teaching. Therefore, in the era of Internet + education, it is essential for business English teachers to make use of online resources such as micro-lessons and MOOCs to carry out flipped classroom teaching activities and boldly innovate the classroom teaching model. Appropriate teaching methods should be chosen according to students' actual situations, and action-oriented teaching methods such as task-driven teaching, role-playing, scenario simulation and other teaching methods should be adopted and integrated into traditional teaching, in business English education to enhance students' enthusiasm for learning[7].

Thirdly, construction of diverse business English teaching resources. The business English teaching model based on Internet Plus employs modern education information technology to develop teaching resources and innovate teaching methods and approaches. For example, modern education technology is used to produce multimedia courseware that combines text, sound, images and animation to increase the visualization, stereoscopic and vividness of classroom teaching[8]. With the help of Internet platforms and technologies, information-based teaching resources, such as virtual learning scenarios, cultural background knowledge and exotic images, are developed to provide students with rich learning resources, deepen their understanding of business English language learning, enhance the interest of course learning and effectively train students' listening, speaking, reading and other language communication skills. It establishes interactive teaching scenarios for synchronous interactive teaching to meet the needs of students with different learning levels and to realize personalized teaching. A variety of online learning resources can largely compensate for the shortcomings of the current standardized textbooks and establish a new learning structure for business English courses. In addition, online learning on the Internet can promote students' communication with English-speaking people and give them the opportunity to learn English as a linguistic communication tool on their own initiative. Smartphone-based network communication technology, which enables online access to learning resources at any time and real-time communication, extends the time and space for traditional classroom teaching.

\section{LEARNING-CENTERED FORMATIVE EVALUATION OF BUSINESS ENGLISH TEACHING}

Test and evaluation are important means to check the quality of teaching and to promote the construction and development of business English courses. Business English course should be analyzed in a multi-dimensional way to determine whether its target objectives has been achieved or not and whether students' language competence has reached the specified objectives. Teaching evaluation not only exams the teaching effect and students' learning situation, but also an orientation of the teaching process. Traditionally, the evaluation of learning effect is usually done by such ways as asking questions in class, taking tests and doing homework after class. Disadvantages of the traditional ways are one-sided, inefficient, slow to give feedback, and narrow in scope. Such disadvantages make the traditional evaluation ways unable to adapt to the new situation of university English teaching. If teachers cannot get the right feedback from the students, they cannot provide help, cannot guide students accordingly, which in turn will affect students' learning effect and enthusiasm. Reasonable teaching evaluation helps to motivate and guide students to develop in a reasonable direction, thus ultimately improving the teaching effect.

Formative evaluation was first introduced in 1967 by Michael Scriven, a professor of psychology at American University. Formative evaluation refers to the activities that both teachers and students perform when teachers evaluate student learning and students evaluate their own learning. The activities provide information on teaching process. Only when such evaluation activities is used to adjust teaching process and meets the demands of teaching are they referred to be Formative Evaluation[9]. In the teaching and learning process, formative evaluation is the process by which teachers and students judge and evaluate students' learning in order to promote student development[10]. Formative evaluation is student-centered and focuses on student development. Students' learning methods and process outcomes are valued. Constructivism believes that teaching evaluation is pluralistic and diverse in order to encourage students to take responsibility for their own learning process, and self-evaluation is the way to achieve the desired expectations and goals.

In the Internet era, the development of information technology and big data analysis have provided better conditions for the rational implementation of teaching evaluation. In the context of "Internet Plus education", with the help of Internet technology, students' learning can be recorded precisely; more evaluation data can be collected, such as unstructured data other than test scores, including students' usual learning attitudes, classroom performance, the attitude towards and quality of homework etc.. Tracking students' personalized learning process aims at obtaining first-hand information on students' learning status. Data of students' learning process and learning results are recorded in detail based on the concept of big data. Then, through data analysis, problems are identified 
and timely teaching reminders are given to teachers, and teachers will intervene and adjust learners' learning behavior timely. Therefore, when formulating the evaluation plan, we use Internet technology to collect students' various learning performance data, focus on students' learning process assessment, and adopt a diversified evaluation approach. Moreover, students can self-evaluate their own learning and develop learning plans with information technology and resources on the Internet. Learning platform urges learners to complete their studies by punching cards and signing in; it also provides stage assessment and comprehensive assessment to help learners grasp the learning content and help them understand their learning outcome. It also enables learners to raise their interest and enthusiasm in the process of constantly challenging for high scores. Teachers can also use the learning platform to get feedback from students, promptly monitor and guide them, and adjust the teaching content. Through students' learning materials they choose, teachers can know students' learning process and learning pace, and thus provide guidance and supervision to students that they need.

The Formative evaluation indexes and methods of business English teaching based on the Internet are shown in Table 1

Table 1. Formative evaluation table for business English teaching based on Internet Plus

\begin{tabular}{|c|c|c|c|c|}
\hline No. & $\begin{array}{c}\text { Evaluation } \\
\text { index }\end{array}$ & $\begin{array}{c}\text { Student } \\
\text { evaluation }\end{array}$ & $\begin{array}{c}\text { Teacher } \\
\text { evaluation }\end{array}$ & $\begin{array}{c}\text { Big Data } \\
\text { analysis }\end{array}$ \\
\hline 1 & Listening & & & \\
\hline 2 & Speaking & & & \\
\hline 3 & Reading & & & \\
\hline 4 & Writing & & & \\
\hline 5 & $\begin{array}{c}\text { Cultural } \\
\text { Knowledge }\end{array}$ & & & \\
\hline 6 & $\begin{array}{c}\text { Business } \\
\text { Knowledge }\end{array}$ & & & \\
\hline
\end{tabular}

The Formative evaluation of business English teaching changes single test into comprehensive assessment. In other words, in addition to testing students' business English knowledge and skills, students' learning process, learning attitude, English language performance, and their basic qualities and language skills are included in the evaluation system according to teaching objectives of business English courses.

Secondly, the evaluation system is a combination of summative evaluation and formative evaluation. In addition to the final exam, students' usual performance and stage test results are also included in the evaluation system. Students' usual performance includes class attendance, participation in classroom activities, homework completion, group work, presentation and self-innovation task, etc. Stage tests mainly refer to quizzes and unit tests, such as vocabulary tests, dialogues, role play, oral expressions, and writing exercises, etc. The three parts, students' usual performance, stage tests and final exams take up a certain proportion in the evaluation system. This evaluation system urges students to develop good study habits, increase their interests in English learning, and improve their enthusiasm for learning English.

Thirdly, the evaluation system proposed is developmental The traditional evaluation was more of a rewarding and punishing evaluation, that is, good students are praised while those are punished. In the new evaluation system, the purpose is to let students know how well they performed in each process and in which direction they can do better.

\section{LEARNING-CENTERED BUSINESS ENGLISH TEACHING PRACTICE}

Experimental teaching is designed and carried out in the study to test the effectiveness of the new teaching mode. The study selects two parallel classes of business English major. Class 1 is still taught with traditional model and Class 2 with the learning-centered business English teaching model. Comparison is made two years later. For Class 2, teaching documents and learning resources are created and constructed on the business English Learning Resources Sharing Platform. Before class, students are guided to preview independently online through completing the tasks provided online by teachers. During online self-study process, students select the learning resources created by teacher; the length of online learning time is decided by the students, students with a good foundation spending less time and students with a poor foundation spending more time, thus maximizing the needs of students with different foundations and realizing individualized learning. In this phase, students find the difficult points in the teaching content, and teachers get right feedback from students.

After online pre-study, students attend classroom teaching with their difficult points and confusions. Teachers will focus on explaining the emphasis and difficult points, answering the questions from students, and solving the problems of students. Different activities are designed previously by the teachers, such as discussion, brainstorming, group task, cooperative study, presentation, etc.. Teachers create as many realistic business and language contexts as possible to enable students work together in class and share their learning results.

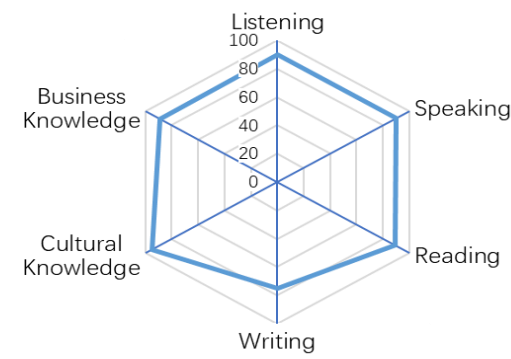

Figure 2. Formative multivariate evaluation of student course learning

After class, students view the multimedia learning materials of the course on the Learning Platform. If they 
haven't understood the teacher's explanation well in class, they can download the contents to their cell phones or computers to study again. If they encounter any problems that cannot be solved, they can also ask for help online and send their questions to the teacher via Internet. Teachers take turns being on duty online to answer students' questions and providing timely help and guidance. Exercises and quizzes are provided online after each class. Through exercises and quizzes, both students and teachers know the teaching and learning effect immediately.

Under the new teaching model, a formative multivariate evaluation system is adopted to assess the teaching and learning effect, as shown in Fig.2.

In the process of evaluation, teachers not only focus on students' overall test scores, but also on their performance in the whole process of learning. The course learning is subdivided into several dimensions, including listening comprehension, oral expression, reading comprehension, writing, cultural knowledge and business knowledge. Each dimension has self-evaluation, peer evaluation and teacher evaluation. The learning platform also tracks and records each student's learning process. Based on big data analysis, the learning platform provides formative evaluation for each dimension. Such quantitative evaluation results are of strong guidance to both students and teachers to conduct targeted teaching and learning activities to remedy learning deficiencies. In the process of teaching evaluation, for those students who have a poor foundation in English, teachers try their best to find or explore their positive aspects, such as active participation in class, good oral expression, and improvement they have made, etc., and praise and encourage them. The study conducted a questionnaire survey on the students who participated in the experimental teaching with the new teaching model and the results are shown in Table 2.

Table 2. Questionnaire survey on the effectiveness of new business English teaching model

\begin{tabular}{|c|l|c|}
\hline No. & \multicolumn{1}{|c|}{ Survey indicators } & $\begin{array}{c}\text { Acceptance } \\
(\%)\end{array}$ \\
\hline 1 & Rich learning resources & 93.3 \\
\hline 2 & Innovative teaching methods & 83.3 \\
\hline 3 & Effective business scenarios & 90 \\
\hline 4 & Various teaching activities & 80 \\
\hline 5 & Good teacher-student interaction & 86.7 \\
\hline 6 & Convenient autonomous learning & 83.3 \\
\hline 7 & Easy to use fragmented time & 86.7 \\
\hline 8 & Effective evaluation & 90 \\
\hline
\end{tabular}

According to the questionnaire survey, $93.3 \%$ of the students thought that the teaching and learning resources were abundant and they could choose flexibly to meet their needs; $83.3 \%$ of the students thought that the teaching methods were innovative and varied; $80 \%$ of the students thought that the classroom activities made learning more interesting and effective; $86.7 \%$ of the students thought that they could further enhance their interaction with the teacher and other students online, and $90 \%$ of the students thought that the evaluation was very highly targeted and more conducive to improving learning.
It can be said that micro-classes, MOOCS and flipped classrooms have brought a new concept and reform to English classroom teaching, and are welcomed by students. The traditional "teacher, book, classroom"-centered teaching model will gradually give way to a new "student, problem, activity"-centered teaching model based on the Internet Plus and learning resources online. This online and offline blending of flipped classroom teaching is bound to become a new mode of business English classroom teaching.

Data are collected in Class 1 and Class 2. Comparison results are shown in Fig.3 and Fig.4.

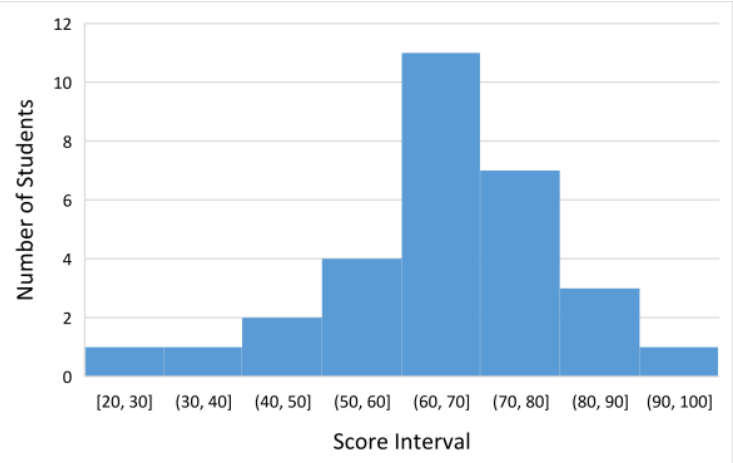

Figure 3. Performance distribution of Class 1 in traditional teaching model

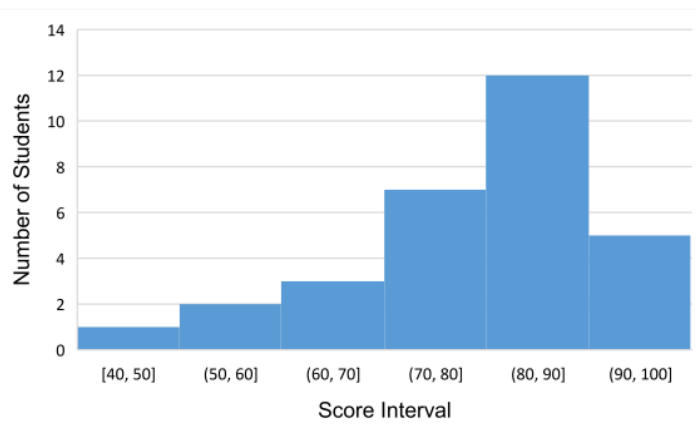

Figure 4. Performance distribution of Class 2 in the new learning-Centered teaching model

As the figures show, the average grade of class 2 using the new teaching model has increased by $20.8 \%$, the number of students who fail has decreased by $62.5 \%$, and the number of "excellent performance" has increased by $325 \%$ compared with class 1 using the traditional teaching model. The results show that the learning-centered business English teaching model in the context of Internet Plus is accepted by students and has achieved better teaching results.

\section{CONCLUSION}

Internet plus will surely bring profound changes to higher education. Business English teachers should actively update their teaching concepts, innovate teaching theories, improve teaching approaches by using modern information technology, integrate teaching resources, establish a new 
evaluation system, and form new teaching model. Experimental results in the study show that this new learning-centered business English teaching model enriches business English teaching resources, promotes teacher-student interaction, improves students' enthusiasm for learning business English, eases their learning pressure, and enhances the effectiveness of business English teaching. The new learning-centered teaching model based on Internet plus can encourage students to maximize their potential, which is in line with the current needs of higher education talent cultivation.

\section{ACKNOWLEDGMENT}

This study was supported by a grant of Education Science Research Project "Research Learning-Centered English Classroom Teaching Model in Higher Vocational College" (No.Jk201908) supported by Beijing Union University.

\section{REFERENCES}

[1] Jianzhu Liu, "Research on the Application of OBE Concept in the Training of business English Majors in Higher Vocational Colleges", Business Foreign Language Research, 2019, vol.2, pp.68-73. (In Chinese)

[2] Youliang Zhang, and Junjie Shang, "Internet Plus and Prospects of China's Higher Education Reform", Modern Distance Education Research, 2018, vol.1, pp.15-23. (In Chinese)

[3] M. Tam. "Constructivism, instructional design, and technology: implications for transforming distance learning", Educational Technology \& Society, 2000, vol. 3, pp.50-60.
[4] Marion Williams and Bob Burden. "Psychology for Language Teachers: A Social Constructivist Approach". Cambridge: Cambridge University Press, 2000.

[5] Graham C. R., Woodsfield W., and Harrison J. B., "A Framework for Institutional Adoption and Implementation of Blended Learning in Higher Education", Internet \& Higher Education, 2013, vol.3, pp.4-14.

[6] He Jie, "The Variant Practice and Enlightenments of Flipped Classroom Teaching Mode - Based on an Empirical Study of English Language Teaching in Higher Vocational Colleges", Vocational and Technical Education, 2016, vol.37, pp.29-32. (In Chinese)

[7] Yen J. C., and Lee C. Y., "Exploring Problem Solving Patterns and Their Impact on Learning Achievement in A Blended Learning Environment", Computers \& Education, 2011, vol.1, pp.138-145.

[8] Dunhai Wang, Zili Ma, and Xijin Zhang, "Education and Educational Technology", Springer Heidelberg: 2011 .

[9] Black, P., and William, D., "Inside the black box: Raising standards through classroom assessment", Phi Delta Kappan, 1998.

[10] Leung C., and Mohan B., "Teacher formative assessment and talk in classroom contexts: assessment as discourse and assessment of discourse", Language Testing, 2004, vol.1, pp.335-359. 